\title{
NARASI PENDIDIKAN DARI TANAH BETAWI: Pemikiran Sayyid Usman tentang Etika Akademik
}

\author{
Radinal Mukhtar Harahap \\ Sekolah Tinggi Ilmu Tarbiyah Ar-Raudlatul Hasanah \\ Jl. Setia Budi, Simpang Selayang, Medan, Sumatera Utara, 20135 \\ e-mail: radinalmukhtarhrp@gmail.com
}

\begin{abstract}
Paedagogical Narrative from Betawi Land: Sayyid Usman's Thoughts on Educational Ethics. This study examines Sayyid Usman's thinking concerning the ethics of education in an Islamic perspective. This study is necessary considering the scarcity of research on local scholars who have contributed to the field of Islamic education. This article is the result of library research that relies on the method of content analysis, and proposes findings that Sayyid Usman wrote a work in the field of ethics, entitled Âdâb al-Insân. This book is relatively under-researched in the perspective of Islamic education. Based on a review of this archipelago script, the author emphasizes that education is the main solution in improving the ethics of bad people by teaching a series of âdâb which covers aspects of personality, social and professionalism. This study contributes to the strengthening of the literature in the field of Islamic education considering that there are not many Nusantara figures introduced and studied in Islamic Higher Education institutions.
\end{abstract}

Keywords: education, ethics, archipelago, Betawi, Sayyid Usman 


\section{Pendahuluan}

Telaah terhadap beberapa literatur menunjukkan bahwa tidak banyak gagasan pendidikan ulama lokal Nusantara dikenalkan dan dipelajari. Kemungkinan hal ini terjadi lantaran masih sedikitnya riset-riset yang dilakukan terhadap ulama lokal Nusantara. Kemudian, para penulis dalam bidang pemikiran pendidikan Islam kurang mengakomodir gagasan yang ditampilkan oleh tokoh lokal. Padahal, Indonesia memiliki banyak ulama dan menuangkan gagasannya dalam bidang pendidikan Islam dalam karya-karya mereka. Pengenalan terhadap gagasan ulama Nusantara terutama dalam bidang pendidikan penting dilakukan agar generasi penerus bangsa Indonesia tidak abai terhadap khazanah yang dimiliki negaranya.

Sayyid Usman, dalam penilaian Azyumardi Azra, adalah ulama yang paling terkemuka pada abad ke-19 dan awal abad ke-20 di Nusantara. ${ }^{1}$ Kedudukannya sebagai ulama, bukan hanya menjadikannya sebagai subjek yang membahas banyak hal terkait problematika masyarakat, yang dituangkan lewat fatwa atau karyakarya tulisnya, melainkan sosoknya sendiri adalah objek yang diperbincangkan karena dirinya memegang posisi penting dalam administrasi kolonial Belanda di Hindia Belanda. Ia adalah teman dari orientalis bernama Snouck Hurgronje. ${ }^{2}$ Gambaran ringkas sosoknya tersebut kiranya cukup untuk menjadikannya tokoh yang layak diteliti, dengan pedoman tiga komponen gagasan Syahrin Harahap mengenai biografi tokoh. Pertama, integritasnya sebagai seorang ulama yang hidup di akhir abad 19 dan awal abad ke-20 dengan kedalaman pemikiran dan ilmunya. Kedua, karya-karya monumentalnya yang mencapai 48 buku, dari versi Ahmad Fauzi Ilyas, ${ }^{3}$ dengan berbagai tema. Ketiga, kontribusi dan pengaruhnya yang dirasakan secara nyata oleh masyarakat, baik dalam bentuk pikiran maupun bentuk aksi. ${ }^{4}$ 
Studi ini mengkaji pemikiran Sayyid Usman bin Abdullah bin Aqil bin Yahya al-Alawi (w. 1914 M) dalam bidang pendidikan Islam, khususnya masalah etika akademik pendidik dan peserta didik. Secara khusus, dengan metode analisis isi, studi ini akan mengkaji karyanya yang berjudul Âdâb al-Insân. Diharapkan dari studi ini akan muncul gambaran mengenai bagaimana perhatian sosok yang diteliti terhadap dunia pendidikan. Penelitianpenelitian sebelumnya, baik dalam bentuk disertasi, ${ }^{5}$ kertas kerja konferensi ${ }^{6}$ atau artikel berkala ilmiah, ${ }^{7}$ belum banyak melihat kontribusinya dalam dunia pendidikan, karena para peneliti masih lebih menyoroti pemikiran-pemikiran keagamaannya terutama dalam lingkup syariah, akidah, dan tasawuf, termasuk perihal kontroversi kedudukannya yang memang selalu menarik untuk dibicarakan. Demikian pula hasil penelitian Jajat Burhanuddin, ${ }^{8}$ Mansur, ${ }^{9}$ Nurhasanah, ${ }^{10}$ atau Ahmad Athoillah ${ }^{11}$ yang juga belum menyentuh secara nyata aspek khusus dalam dunia pendidikan. Untuk keperluan itu, studi ini akan menelaah biografi Sayyid Usman dan pemikiran pendidikannya sebagaimana yang terdapat dalam kitab Âdâb al-Insân sebagai karyanya menjadi fokus kajian. Studi ini akan melengkapi gugusan karya dalam bidang etika akademik dalam pendidikan Islam, dan beberapa pemikiran tokoh seperti Ibn Jamâ'ah, ${ }^{12}$ al-Ghazâlî, ${ }^{13}$ al-Zarnuji, al-Nawawî, ${ }^{14}$ Hasyim Asy ari ${ }^{15}$ dan Hasan Maksum al-Deli ${ }^{16}$ telah dikaji berkaitan dengan masalah etika akademik ini.

\section{Biografi Sayyid Usman}

Sayyid Usman, dalam keterangan anaknya yang bernama Sayyid Abdullah, adalah seorang Mufti Betawi yang dilahirkan 17 Rabiul Awal 1238 H. Ia mempunyai ayah yang bernama lengkap Sayyid Abdullah bin Aqil bin Umar bin Yahya yang lahir di Mekah. Sayyid Aqil bin Umar bin Yahya, kakeknya, juga dilahirkan di Kota Suci tersebut. Adapun buyutnya, Sayyid Umar 
bin Yahya, lahir di Hadramaut, tepatnya di kampung bernama Qârah al-Syaikh. ${ }^{17}$ Gelar Sayyid ${ }^{18}$ yang tersemat di awal namanya memberi gambaran bahwa dirinya tergolong sosok yang mempunyai silsilah hingga ke Nabi Muhammad SAW. ${ }^{19}$ Menurut Muhammad Noupal yang meneliti manuskrip tulisan Sayyid Usman yang berjudul Hâdzihi al-Syâjarah al-'Âliyah fî al-Rawdhah al-Saniyah dan 'Aqd al-Jumân fî Adâb Tilâwat al-Qur'ân, menemukan rincian lengkapnya sebagai berikut: ${ }^{20}$

'Utsmân bin 'Abdullâh bin 'Aqil bin 'Umar bin 'Aqil bin Syekh bin 'Abdurrahmân bin 'Aqil bin Ahmad bin Yahya bin Hasan bin 'Ali bin 'Alwi bin Muhammad Mawla al-Dawilah bin 'Ali bin 'Alwi bin Muhammad Fâqih Muqaddam bin 'Ali bin Muhammad Shâhib Mirbath bin 'Ali Khala' Qasam bin 'Alwi bin Muhammad bin 'Alwi bin 'Ubaidillâh bin 'Ahmad al-Muhâjir bin 'Isa bin Muhammad al-Naqib bin 'Ali al'Uraidhi bin Ja'far Shâdiq bin Muhammad al-Baqir bin 'Ali Zainal 'Abidin bin Husein bin 'Ali bin Abi Thâlib dengan Fâthimah binti Muhammad SAW.

Sayyid Usman dilahirkan di tanah Betawi, ${ }^{21}$ tepatnya di Pekojan. ${ }^{22}$ Wawancara yang dilakukan Nico J.G. Kaptein kepada M.A. Alaydrus mengarahkan tempat kelahirannya di daerah Angke yang berada sekitar $7 \mathrm{~km}$ sebelah barat Batavia. ${ }^{23}$ Peneliti asal Leiden University itu juga mengkonversi tanggal lahir Sayyid Usman tersebut di atas dan mendapatkan bahwa tanggal itu bertepatan dengan tanggal 1 Desember $1822 .{ }^{24}$

Sayyid Usman, sejak umur tiga tahun, telah ditinggal sang ayah yang kembali ke negeri asalnya, yaitu Mekah, dengan berlayar. Dalam hal tersebut, si ayah membawa putra sulungnya bernama Sayyid Hasyim bin Abdullah bin Aqil bin Yahya. Sejak itu, Sayyid Usman diasuh oleh Syaikh Abdurrahman al-Mishri, yaitu kakeknya dari pihak ibu. Ibunya sendiri bernama Aminah 
binti Abdurrahman al-Mishri. Di bawah pengasuhan sang kakek, ia mendapat berbagai macam pelajaran. ${ }^{25}$

Mengenai kakeknya, Rakhmad Zailani Kiki dari Pusat Pengkajian dan Pengembangan Islam Jakarta (Jakarta Islamic Centre) menerangkan bahwa ia adalah suami dari salah satu anak perempuan Syaikh Junaid, seorang ulama yang disebut sebagai poros keislaman di Betawi. Syaikh Junaid ini adalah ulama yang lahir di Pekojan dan berpengaruh di Mekah meskipun hanya enam tahun bermukim di sana. Ia adalah Imam Masjid al-Haram dan Syaikh al-Masyâyikh terkenal di dunia Islam Sunni dan mazhab Syâfíi sepanjang abad ke-18 dan $19 .{ }^{26}$

Selain itu, banyak data yang mengungkapkan bahwa kakek Sayyid Usman tersebut adalah pakar dalam bidang astronomi dan astrologi. Keahliannya itu di antaranya diajarkan pada sang cucu, Sayyid Usman. Raja Ali Haji menulis sekilas tentang Syaikh Abdurrahman al-Mishri diTuhfat al-Nafis, yang mengatakan "Raja Ahmad itu pergi berulang-ulang mengaji ilmu falakiya kepada Syekh Abd al-Rahman Misri di dalam Betawi itu." ${ }^{27}$ Snouck Hurgrounje, dalam nasihat-nasihatnya semasa kepegawaian di Hindia-Belanda 1889-1936, juga menceritakan kiprahnya di bidang astronomi-astrologi yang berhasil menyelesaikan permasalahan arah kiblat di masjid Palembang, meskipun mula-mula mendapat pertentangan dari orang-orang berpengaruh di lingkungan Sultan, bahkan dilecehkan. ${ }^{28}$

Penjelasan di atas, paling tidak, menggambarkan bahwa sosok Sayyid Usman adalah pribadi yang memiliki kemuliaan dan kehormatan secara geneologi kehidupan. Ia lahir dari seorang ayah yang mempunyai sanad hingga ke Rasulullah, dan ibu yang mempunyai gen keilmuan mumpuni dalam diri Syaikh Abdurrahman al-Mishri dan Syaikh Junaid Betawi. Ketika kecil hingga umur 19 tahun, ia juga langsung diasuh oleh sang kakek, sehingga besar kemungkinan lingkungan yang berkembang 
ketika ia tumbuh adalah lingkungan yang memiliki kultur keilmuan yang kokoh.

Kemuliaan itu juga tampak dalam riwayat pendidikannya. Sayyid Usman, sebagaimana disebut sekilas di atas, mulai belajar ilmu-ilmu Islam dari pengajaran yang diberikan oleh Syaikh Abdurrahman al-Mishri, sang kakek. Hal itu karena ketika umur tiga tahun, ayahnya Sayyid Abdullah bin Aqil bin Umar bin Yahya pulang kembali ke Mekah. Rentang waktu bersama sang kakek, ia mempelajari berbagai ilmu adab beserta adat istiadat yang sopan. Ia juga dikenalkan ilmu-ilmu agama, yang dimulai dari pengetahuan mengenai huruf Arab, cara membaca Alquran, tajwid, tauhid, fikih, tasawuf dan ilmu-ilmu alat yang menjadi bagian tata bahasa Arab seperti saraf dan nahu. Sayyid Usman juga diajari ilmu tafsir, hadis, astronomi, astrologi dan ilmuilmu Islam lainnya. ${ }^{29}$ Ilmu-ilmu itu yang dalam perkembangannya menjadi pengantar bagi Sayyid Usman mendalami ilmu-ilmu lain kepada guru-gurunya di Mekah dan Hadramaut.

Nico J.C. Kaptein, mengutip Buno Heslinga, mencatat bahwa Syaikh Abdurrahman al-Mishri juga pernah memperkenalkan Sayyid Usman muda kepada Gubernur Jenderal P. Merkus (18411844). Bisa jadi, ini awal baginya mengenal sistem pemerintahan. Hal itu terjadi ketika tahun 1899, Sayyid Usman pergi ke istana untuk menyampaikan terima kasih atas bintang kehormatan yang diterimanya. Waktu itu, ia memperhatikan gambar mantan Gubernur Jenderal P. Merkus (1841-1844), dan langsung teringat kepada sosok yang pernah ia temui saat masih muda, ketika menemani kakeknya melakukan audiensi di istana yang sama. ${ }^{30}$ L.C.W Van Den Berg memang menceritakan bahwa Syaikh Abdurrahman al-Mishri adalah sosok yang dihormati penguasa Belanda. ${ }^{31}$ Namun, jika mengacu kepada tahun P. Merkus menjabat sebagai Gubernur Jenderal (1841-1844), cerita ini perlu diperiksa kebenarannya mengingat tahun $1257 \mathrm{H} / 1841 \mathrm{M}^{32}$ adalah tahun 
keberangkatan Sayyid Usman ke Mekah untuk haji dan bertemu dengan sanak keluarganya serta melanjutkan proses pembelajaran hingga Hadramaut. Ia sendiri baru pulang ke Batavia, dalam keterangan anaknya Sayyid Alwi bin Usman bin Abdullah bin Aqil bin Umar bin Yahya di Qamar al-Zamân pada tahun (1279 H) $1862 \mathrm{M}^{33}$

Setelah menimba ilmu dari sang kakek pasca wafatnya sang ibu, Aminah binti Abdurrahman al-Mishr, ${ }^{34}$ Sayyid Usman meminta izin untuk berangkat ke Mekah untuk menunaikan Haji sekaligus bertemu dengan ayahnya dan sanak keluarga di sana tahun $1257 \mathrm{H}$ di bulan Rajab. ${ }^{35}$ Menurut Kaptein, itu adalah tahun $1841 .{ }^{36}$ Dengan konversi itu, Kaptein memastikan bahwa umur Sayyid Usman ketika berangkat adalah 19 tahun $^{37}$ sebagaimana tercantum dalam Qamar al-Zamân, ${ }^{38}$ bukan 18 tahun seperti yang ditulis Sulûh Zamân. ${ }^{39}$ Dua biografi karya dua anak Sayyid Usman itu berbeda dalam menentukan umur tokoh ayah mereka berangkat pertama kali ke Mekah.

Sayyid Usman menetap selama tujuh tahun di Mekah. Selain untuk berkumpul dengan ayah dan sanak keluarganya, ia juga menuntut ilmu kepada Syekh Ahmad Zaini Dahlân. ${ }^{40}$ Kaptein menjelaskan bahwa kepada ulama yang disebutkan namanya terakhir ini, Sayyid Usman belajar banyak dan memiliki hubungan yang akrab karena dirinya adalah asisten dalam beberapa waktu di majelis-majelis keilmuan gurunya. Keakraban itu bahkan terus berlangsung hingga sang guru meninggal dunia tahun 1886. ${ }^{41}$ Buku Sayyid Usman yang berjudul I'anât al-Mustarsyidîn 'alâ Ijtinâb al-Bida' fî al-Dîn, meskipun baru diterbitkan tahun 1911, memuat surat pujian (taqrîz) dari Mufti Syâfi'i di Mekah tersebut. ${ }^{42}$

Selain dua daerah tersebut, riwayat pendidikan Sayyid Usman juga terdapat di daerah Hadramaut, asal dari buyutnya, Sayyid Umar bin Yahya. Ia berangkat ke daerah itu setelah tujuh tahun 
berada di Mekah, tepatnya $1264 \mathrm{H} / 1847 \mathrm{M} \cdot{ }^{43}$ Kaptein mencatat bahwa lama bermukim Sayyid Usman di Hadramaut adalah 15 tahun (1847-1862 M). Di sana, kemungkinan besar ia menetap di daerah Masilat al-Syekh, meskipun tidak terdapat data kongkrit yang menjelaskannya. Kemungkinan itu hanya karena di sana ada perpustakaan penting milik al-Yahya, guru yang pendapatnya banyak dikutip oleh Sayyid Usman sepanjang karir keulamaan dan intelektualnya. ${ }^{44}$

Penting untuk diketahui bahwa masa di mana Sayyid Usman berkunjung ke Hadramaut (1847-1862) adalah masa di saat wilayah itu kurang stabil di bidang politik. Waktu itu, dalam catatan Ulrike Freitag, kawasan Hadramaut sedang terbagi-bagi menjadi beberapa wilayah dan penguasa antar wilayah saling bersaing. ${ }^{45}$ Namun demikian, penting juga dipahami bahwa kebangkitan kaum Hadrami dalam bidang pemikiran juga tidak jauh dari masa keberadaan Sayyid Usman di sana, yaitu 1880-1930. ${ }^{46}$ Besar kemungkinan, semangat yang diistilahkan Freitag dengan sebutan renaisance atau nahdhah itu juga berimbas pada kehidupan Sayyid Usman ketika sudah mendarat di Indonesia, tepatnya di Batavia, 1862. Hal itu terlihat dari pandangan Karel A. Steenbrink yang mengatakan bahwa tokoh ini merupakan salah satu yang terkemuka di Indonesia dalam gerakan pembaruan Islam. ${ }^{47}$

Dalam perjalanan di Timur tengah, 1855-1856, riwayat pendidikan Sayyid Usman juga ada di Madinah, Hijaz, Mesir, Tunisia, Aljazair, Turki, bahkan Perancis, Yerussalem dan Singapura. Untuk beberapa kota di atas, selain Madinah dan Hijaz, Nico J.G. Kaptein menganalisa bahwa sumber datanya hanya Sulûh Zamân dan Qamar al-Zamân. Data itu tidak dapat dikonfirmasi dengan sumber-sumber yang lain, sebagai pendukung atau pembenar. Dua sumber yang dimaksud, karena berasal dari keluarga Sayyid Usman sendiri, disinyalir kebenarannya hanya terkait dengan pencitraan kebaikan yang dibawakan oleh keluarga Sayyid Usman itu sendiri. ${ }^{48}$ Namun 
demikian, dari sketsa kehidupan dan pendidikan di atas, Sayyid Usman kemudian tumbuh menjadi seorang ulama yang produktif menghasilkan karya. Ahmad Fauzi Ilyas mendata judul-judulnya sebagai berikut: ${ }^{49}$

1. Al-Adillah 'alâ Syurûth Syuhûd al-Ahillah (rukyah hilal);

2. Al-Qawânin al-Syar iyyah li Ahl al-Majâlis al-Hukumiyah wa al-Iftâ'iyah (fikih: bahasa Jawi);

3. Ta 'bîr Aqwa Adillah;

4. Jâmi áh al-Fawâ’id;

5. Sipat Dua Puluh (akidah: bahasa Jawi);

6. Irsyâd al-Anâm (bahasa Jawi);

7. Zahr al-Basîm (bahasa Jawi);

8. Ishlâh al-Hîal;

9. Al-Tuhfah al-Wardiyah;

10.Silsilah Alawiyah;

11. Al-Thariq al-Shahîh $\underline{h}$ ah;

12. Taudhîh al-'Adillah;

13. Maslak al-Akhyâr (amalan: bahasa Jawi);

14. Sa âdah al-Anâm;

15. Nafầis al-Nihlah;

16. Kitâb al-Farâ'idh;

17. Shagâ’una Sahâya;

18. Muthâla'ah;

19. Soal Jawab Agama (fatwa: bahasa Jawi);

20. Tujuh Faedah (bahasa Jawi);

21. Al-Nashîhah al-'Anîqah (bahasa Jawi); 
22. Khutbah Nikah;

23. Al-Qur'ân wa al-Du’â;

24. Ringkasan Ilmu Adat-Istiadat,

25. Ringkasan Seni Membaca al-Qur'an;

26. Membahasa al-Qur'an dan Kesalahan dalam Berdoa;

27. Ringkasan Unsur-unsur Doa;

28. Ringkasan Tata Bahasa Arab;

29. Al-Silsilah al-Nabawiyah;

30. Atlas Arabi;

31. Gambar Mekah dan Madinah;

32. Perhiasan Bagus (nasihat untuk wanita: berbahasa Jawi);

33. Ringkasan Seni Menentukan Waktu Sah Untuk Shalat;

34. Ilmu Kalam;

35. Hukum Perkawinan;

36. Ringkasan Hukum Pengunduran Diri Istri Secara Sah;

37. Ringkasan Undang-undang Saudara Susu;

38. Buku Pelajaran Bahasa dan Ukuran Benda;

39. Âdâb al-Insân (adab: bahasa Jawi);

40. Kamus Arab-Melayu;

41. Cempaka Mulia;

42. Risalah Dua Ilmu (pembagian ulama: bahasa Jawi);

43. Bab al-Minan;

44. Keluarga;

45. Khawâriq al-Âdat,

46. Kitab al-Manâsiq;

47. Ilmu Falaq. ${ }^{50}$ 


\section{Sistematika Konten Kitab Âdâb al-Insân}

Buku ini, dalam catatan Nico J.G. Kaptein diterbitkan pada Agustus $1885 .{ }^{51}$ Dalam versi yang diteliti untuk tulisan ini, tidak ada keterangan tersebut, baik di halaman sampul, halaman awal, maupun halaman terakhir yang biasanya dijadikan tempat keterangan tahun terbit. Perwajahannya sudah seperti bukubuku modern, yang menggunakan kertas berbeda antara sampul luar dengan sampul dalam. Ilustrasi yang ditampilkan adalah tangan yang sedang berjabat di tengah-tengah sampul sebagai pemisah antara keterangan judul dan keterangan penulis dan penerbit. Tertulis di bagian atas ilustrasi "ini kitab bernama Adâb al-Insân", dan tertulis di bagian bawahnya "diatur oleh alSayyid Usman bin Abdullah bin Aqil bin Yahya al-Alawi" dan keterangan penerbit, "taba'a 'ala nafaqati (yang dicetak dan dibiayai) Maktabah wa Mathba'ah Menara Kudus”. Tidak ada keterangan kota. Ahmad Fauzi Ilyas menjelaskan bahwa penerbit itu ada di Jakarta. ${ }^{2}$

Buku ini, sebagaimana tergambar dari judulnya, berbicara mengenai adab yang berarti sopan santun dan kelakuan yang baik. Ada dua puluh tujuh bahasan yang dijelaskan dalam tiga puluh satu halaman dengan perincian sebagai berikut:

1. Adab hamba kepada Tuhannya. ${ }^{53}$

2. Adab anak-anak kepada ayah bundanya. ${ }^{54}$

3. Adab orang kecil punya kelakuan yang patut kepada orang besar. ${ }^{55}$

4. Adab orang muda kepada orang tua-tua. ${ }^{56}$

5. Adab kelakuan bapak mengajar anak-anaknya. ${ }^{57}$

6. Adab murid kepada guru yang mengajar Alquran atau ilmu agama yang betul ajarannya. ${ }^{58}$

7. Adab mengaji ilmu. ${ }^{59}$ 
8. Adab kelakuan guru yang mengajar. ${ }^{60}$

9. Adab membuat ibadah kepada Allah ta âla. ${ }^{61}$

10. Adab pergi sembahyang Jum'at. ${ }^{62}$

11. Adab pergi sembahyang Hari Raya. ${ }^{63}$

12. Adab pergi menengok orang sakit. ${ }^{64}$

13. Adab pergi melawat ke rumah orang yang kematian. ${ }^{65}$

14. Adab mengantar jenazah. ${ }^{66}$

15. Adab puasa bulan Ramadan. ${ }^{67}$

16. Adab kelakuan pukul beduk. ${ }^{68}$

17. Adab aturan membaca Alquran atau membaca maulud. ${ }^{69}$

18. Adab kelakuan yang menikahkan orang. ${ }^{70}$

19. Adab orang mengawinkan. ${ }^{71}$

20. Adab menjauhkan segala bidah. ${ }^{72}$

21. Adab berduduk di mejana tempat orang kawin atau seumpama. ${ }^{73}$

22. Adab dua laki istri. ${ }^{74}$

23. Adab memeliharakan hak tetangga rumah. ${ }^{75}$

24. Adab menolongi akan orang yang dapat kesusahan terbakar. ${ }^{76}$

25. Adab orang yang pegang suatu pekerjaan dengan makan gaji. $^{77}$

26. Adab kelakuan memberi salam kehormatan satu sama lain. ${ }^{78}$ 27. Adab mengasihani pada orang yang dha îf miskin. ${ }^{79}$

Hal yang menarik untuk dicermati adalah penggunaan Sayyid Usman atas term âdâb dalam nuansa pendidikan. Term ini juga digunakan oleh KH. Hasyim Asy'ari (1871-1947) ${ }^{80}$ yang rentang hidupnya serupa yaitu akhir abad ke-19 hingga awal abad ke-20. Buku KH. Hasyim Asy'ari yang menggunakan term âdâb adalah Âdâb al-'Âlim wa al-Muta'allim yang meski dari 
judul terkesan hanya membahas perihal adab seorang guru dan murid, tetapi juga menyertakan ulasan tentang keutamaan ilmu dan adab seorang Muslim terhadap buku-buku yang dipelajarinya ${ }^{81}$ Syed Muhammad Naquib al-Attas mengatakan bahwa penggunaan kalimat âdâb, sebagaimana dua tokoh di atas, adalah tepat untuk

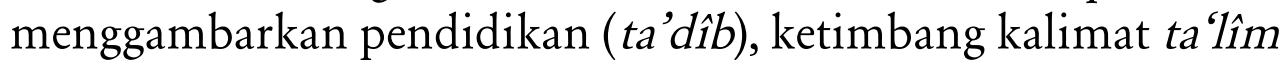
atau tarbiyah. ${ }^{82} \mathrm{Hal}$ itu karena, adab adalah term yang disampaikan Rasulullah SAW., dalam sabdanya yang berbicara mengenai pendidikan. ${ }^{83}$

Latar belakang penulisan buku ini memang erat dengan nuansa pendidikan. Sayyid Usman menjelaskannya di bagian awal buku. ${ }^{84}$

... di zaman sekarang ini banyak orang yang tiada pegang aturan orang-orang baik dan banyak yang tiada kenal adat kelakuan yang baik. Maka, dari itulah terbit segala kejahatan yang membinasakan diri dan membinasakan lain-lain dan menyusahkan hakim. Adapun segala kejahatan itu sebabnya dari karena tiada dapat ajaran yang baik. Adapun ketidakadaan ajaran itu sebabnya dari karena kurang ongkos atau dari karena tiada sempat atau dari karena tiada ada tempat pelajaran.

\section{Pemikiran Pendidikan Sayyid Usman dalam Kitab Âdâb al-Insân Tujuan Pendidikan Islam}

Dari kutipan di atas, dapat dipahami bahwa Sayyid Usman memandang pendidikan Islam sebagai solusi untuk menghilangkan kejahatan yang timbul akibat tidak dipegangnya aturan orangorang baik atau tidak diketahuinya adat kelakuan mereka. Secara ringkas dapat juga dipahami bahwa pendidikan bertujuan memperbaiki tingkah laku seseorang hingga menjadi orang yang baik. Orang baik, dalam hal ini adalah pribadi yang terkumpul dalam dirinya kebaikan hati, kebaikan perangai, kebijakan terhadap menilai 
diri sendiri, halal dalam perbuatan dan selamat dalam tingkah laku. Bijak menilai diri sendiri adalah bijak dalam meraih keuntungan harta, kesenangan badan, ketenangan hati, dan kebaikan nama. Halal dalam perbuatan adalah keterhindaran dari dosa terhadap Allah maupun perkara kepada sesama manusia. Adapun selamat dalam tingkah laku, maksudnya adalah, tidak melanggar aturanaturan agama dan juga tidak melanggar adat-istiadat yang berkembang di negeri. ${ }^{85}$

Dari itu juga terlihat bahwa pendidikan Islam yang dipahami Sayyid Usman tidak hanya sebagai menjalankan nilai-nilai yang terkandung dari agama an sich, melainkan juga mempertimbangkan nilai yang berkembang dalam suatu wilayah yang berbentuk adat-istiadat negeri. Hal ini tidak mengherankan karena sebagai mufti betawi yang juga berkedudukan sebagai adviseur honorair ${ }^{86}$ Belanda, Sayyid Usman perlu untuk memberikan kontribusi dalam melakukan pengawasan, sebagaimana disinyalir oleh Ahmad Baso dalam karyanya yang berjudul Islam Pasca-Kolonial: Perselingkuhan Reformisme Agama, Kolonialisme dan Liberalismeyang mengatakan bahwa sosok Sayyid Usman adalah penemuan kolonial Belanda terkait ordonansi-ordonansi yang mereka tetapkan. ${ }^{87}$ Namun demikian, bukan berarti jabatannya yang disebut terakhir itu yang menjadikan Sayyid Usman memerhatikan perihal adatistiadat negeri, melainkan sosoknya sebagai mufti yang menjadikannya merasa perlu untuk menjaga keselamatan masyarakat sebagaimana diulas Muhammad Noupal terkait dengan kedudukannya sebagai penasihat Snouck Hurgronje. ${ }^{88}$

\section{Etika Akademik dalam Pendidikan}

Kurikulum, secara sederhana, adalah kegiatan dan pengalaman pendidikan yang dirancang, diprogramkan dan diselenggarakan oleh lembaga pendidikan di dalam maupun di luar sekolah dengan maksud untuk mencapai tujuan pendidikan. ${ }^{89}$ Pemaknaan 
seperti itu membawa pemahaman bahwa, dalam konteks karya Sayyid Usman berjudul Adâb al-Insân, dua puluh tujuh adab yang tercantum sebagai isi buku adalah kurikulum yang harus ditanamkan ke dalam diri masyarakat Muslim agar tingkah laku mereka dapat diperbaiki sehingga menjadi orang yang baik. Tidak mengherankan bila kemudian ia menuliskan pesan kepada pembaca kitabnya tersebut, “... Maka, diharap tiap-tiap orang yang mendapat ini kitab serta membaca padanya atau mendengar padanya boleh ia masuk pada bilangan orang-orang baik adanya." ${ }^{\text {90 }}$ Artinya, Sayyid Usman, melalui buku itu, menginginkan agar setiap pembaca dapat meneruskan pengetahuannya mengenai adab-adab yang dibacanya kepada orang-orang yang berada di sekelilingnya.

Dalam pemetaan yang lebih umum, adab-adab tersebut dapat digolongkan kepada tiga kategori. Pertama, katagori kepribadian yang maksudnya adalah personality dari seorang Muslim yang beradab. Hal itu, terlihat ketika Sayyid Usman menekankan perihal adab kepada Tuhan, yang dalam hal ini penting mengacu kepada perihal membuat ibadah, menjauhkan dari segala bidah, seperti diuraikan lebih rinci tentang adab sembahyang Jumat, sembahyang hari raya, puasa bulan Ramadan, dan membaca Alquran dan membaca maulud.

Kedua, kategori sosial, kategori ini merupakan pembahasan yang paling banyak jika diperbandingkan dengan dua lainnya. Kategori ini dimulai dari lingkup yang terkecil, yaitu keluarga hingga lingkup terbesar yaitu masyarakat dan negara. Dalam lingkup keluarga, adab-adab yang dibahas Sayyid Usman adalah adab anak-anak kepada ayah bundanya, adab kelakuan bapak mengajar anak-anaknya, dan adab bersuami-istri. Untuk selanjutnya, adab-adab kepada orang selain dalam rumah tangga sendiri seperti adab memeliharakan hak tetangga rumah, adab orang muda kepada orang tua-tua, adab pergi menengok orang sakit, 
atau melawat ke rumah orang yang kematian, bahkan mengantar jenazahnya, adab menikahkan orang, menghadiri undangan, menolong akan orang yang dapat kesusahan terbakar, dan pada orang yang dha îf miskin. Untuk konteks yang lebih luas, bernegara, ada dua pembahasan yang diketengahkan, yaitu kelakuan memberi salam kehormatan satu sama lain, dan adab orang kecil punya kelakuan yang patut kepada orang besar.

Ketiga, kategori profesionalitas. Hal ini terkait dengan gelar pekerjaan yang tersemat dalam diri seseorang. Profesi guru disebut Sayyid Usman dalam konteks mengaji ilmu, ataupun mengajar. Profesi lain yang juga disebutkan adalah pemukul beduk. Adapun secara umum, ia berpesan dalam adab orang yang pegang suatu pekerjaan dengan makan gaji, yaitu hendaklah amanah, hendaklah pandai mengerjakan kerjaannya, hendaklah menjaga baik-baik pekerjaannya, dan harus rajin memperbaiki kinerjanya. Dengan empat itu, seseorang akan memeroleh empat keuntungan, yaitu nama baik, disayang yang empunya pekerjaan, dipuji, dan rezekinya halal-mulia.

Penyampaian mengenai adab-adab tersebut di atas yang membutuhkan komponen-komponen dasar pendidikan. Komponen ini dijelaskan Sayyid Usman dalam ungkapan berikut: ${ }^{91}$

Adapun sebabnya kepandaian manusia yang sempurna buat mendapati segala kebajikan yang tersebut maka adalah itu sebabnya tiga perkara. Pertama dari sempurna akalnya yakni pikirannya yang baik. Kedua dari ajaran guru-guru yang betul ajarannya dengan kitab-kitab yang mu'tamad. Ketiga dari bercampurnya kepada orang baik-baik hingga ia dapat turut kelakuan baik.

Dari ungkapan tersebut, Sayyid Usman seperti hendak mengatakan bahwa tujuan dan kurikulum yang telah dijelaskan sebelumnya, tidak akan terwujud dalam bentuk nyata jika tidak diperankan dengan baik oleh tiga komponen pendidikan Islam 
berikut ini. Pertama, peserta didik dimana peserta didik harus merupakan murid yang berpikiran baik, lebih-lebih kepada gurunya. Ia, dalam fashl adab murid kepada guru yang mengajar quran atau ilmu agama yang betul ajarannya, mesti menghormati gurunya meskipun sang guru telah diberi gaji atas pengajarannya itu. Sayyid Usman mengatakan bahwa penghormatan murid kepada guru adalah sebab segala kebajikan dunia akhirat. Penghormatan akan mendatangkan berkah ilmu yang itu tidak dapat diganti dengan upah. Sayyid Usman mencela murid yang tidak menghormati gurunya sebagai murid yang tidak mendapat berkah ilmu. Bahkan, Sayyid Usman mengatakan jika ada murid yang dengki pada gurunya atau berbuat jahat kepadanya, ialah murid yang paling jahat di dunia bahkan di akhirat.

Berikut ungkapan lengkap Sayyid Usman mengenai hal itu: ${ }^{22}$

Bermula fardhu atas anak murid bahwa ia memberi hormat kepada gurunya sekalipun ajarannya itu dengan upah sebab segala kebajikan dunia akhirat yang anak murid dapat itu sebabnya dari lantaran gurunya punya ajaran dan punya pertunjukan maka segala kebajikan itu tiadalah ada hingganya maka sekadar hormatnya anak murid kepada gurunya sebegitulah ia dapat berkah ilmunya yakni gunanya di dunia dan di akhirat. Adapun orang yang tiada hormat kepada gurunya maka tiadalah dapat berkah ilmunya. Adapun orang yang berdengki pada gurunya atau membalas jahat kepadanya, maka itulah sehabis-sehabis jahat di dunia dan di akhirat jua adanya.

Kedua, pendidik, yaitu guru dimana guru harus betul-betul dalam mengajarkan ilmunya. Ilmu yang didapat guru haruslah ilmu yang berasal dari kitab-kitab yang mu'tamad. Mengenai ini, dalam buku yang lain berjudul Risâlah Dua Ilmu, Sayyid Usman mengkategorikan guru kepada dua, sebagaimana Rasul membagi ilmu kepada dua; ilmu nâfí dan ilmu dhârr. Dalam tanbîh kedua, ia menuliskan: ${ }^{93}$ 
... Bermula bahwasanya ilmu itu adalah ia dua macam: pertamapertamanya ilmu yang terus di hati dengan cahaya iman yang dengan dia dapat mengamalkan dengan ilmu itu maka itulah ilmu yang nâfi' yakni yang manfaatkan orang berilmu dengan dia dan menjadikannya daripada ulama akhirat dan ulama al-âmilin maka inilah yang dikata ilmu nâfí. Dan keduanya ilmu yang tetes dalih (setetes kepura-puraan) saja yakni pandai mengucap lafazh-lafazh segala ilmu saja, dengan tiada mengamalkan dengan ilmu itu, maka inilah ilmu yang dhârr yakni yang men-dharurat-kan orang berilmu dengan dia, dan dinamakannya ulama dunia dan ulama sû́ maka bahwasanya ilmu yang begini telah menjadi saksi atas anak cucu Adam yang berilmu dengan dia adanya.

Ketiga, lingkungan yang baik, dengan bercampurnya kepada orang baik-baik hingga ia dapat turut kelakuan baik. Bahkan, tentang ini, Sayyid Usman juga menggolongkannya kepada adab orang tua kepada anak-anaknya. Ia mengatakan: ${ }^{94}$

Diperintahkan dia bercampur kepada orang baik-baik supaya mendapat ikut kelakuan yang baik dan dicegahkan dia dari pada bercampur kepada orang-orang jahat atau anak-anak yang tiada dapat ajaran sebab itu menarik pada perangai jahat dan dicegahkan pula dari pada mengadu-mengadu seumpama jangkrik atau ayam atau kelapa supaya jangan perangainya suka mengadu satu sama lain ditakuti nanti ia suka adu hadrah atau dua qirẩah atau dua ilmu maka kesudah-kesudahannya itu menjadi kebinasaan dunia akhirat adanya.

\section{Penutup}

Untuk mendudukkan Sayyid Usman sebagai seorang tokoh yang menaruh perhatian terhadap dunia pendidikan, sketsa kehidupannya dan riwayat pendidikannya kiranya cukup untuk menggambarkan hal tersebut. Dalam dirinya ada jalur kemuliaan nasab yang bersambung hingga ke Rasulullah, dan keistimewaan 
ilmu yang ada dari jalur ibunya -kakek sekaligus gurunya, Syaikh Abdurrahman al-Mishri dan Syaikh Junaid Betawi. Dalam langkah pendidikannya, ia juga bertemu dengan guru seperti Syaikh Ahmad Zaini Dahlân, yang diakui otoritasnya sebagai mufti Syâfíi di Mekah. Lebih-lebih setelah itu ia menuliskan banyak karya. Karyanya itu yang merupakan bukti nyata mengenai usahanya dalam melaksanakan pendidikan. Dalam karyanya yang berjudul Âdâb al-Insân, Sayyid Usman menjelaskan bahwa seharusnya pendidikan Islam ditujukan kepada arah melahirkan orang-orang yang baik, dan memperbaiki orang-orang yang jahat. Pendidikan adalah solusi untuk itu dengan mengajarkan adab-adab yang melingkupi tentang kepribadian, sosial, dan profesionalitas pekerjaan. Dalam hal itu, diperlukan dukungan dari komponen-komponen dasar dunia pendidikan, yaitu pendidik, peserta didik dan lingkungan pendidikan.

\section{Pustaka Acuan}

Al-Attas, Syed Muhammad Naquib. The Concept of Education in Islam: A Framework for An Islamic Philosophy of Education. Kuala Lumpur: ISTAC, 1999.

Al-Jambânî, Muhammad Hasyim Asy'arî. Âdâb al-'Âlim wa alMuta'allim: fî Mâ Yahtaj Ilaih al-Muta'allim fî Ahwâl Ta'allumih wa mâ Yatawaqqaf 'Alaih al-Mu'allim fî Maqâmât Ta 'lîmih. Jombang: Pustaka Tebu Ireng, 2016.

As'ad, Mahrus. 'Pembaruan Pendidikan Islam K.H. Hasyim Asy'ari," dalam Tsaqafah: Jurnal Peradaban Islam, Vol. 8, No. 1, 2012.

Asari, Hasan. "The Educational Thought of al-Ghazali: Theory and Practice." Thesis: McGill University, 1993.

Asari, Hasan. Etika Akademis dalam Islam: Studi tentang Kitab Tazkirat al-Sami wa al-Mutakallim karya Ibn Jama’ah. Yogyakarta: Tiara Wacana, 2008. 
Athoillah, Ahmad. "Kritik Sayid Utsman bin Yahya terhadap Ideologi Jihad dalam Gerakan Sosial Islam pada Abad 19 dan 20," dalam Refleksi, Vol. 13, No. 5, Oktober 2013.

Azra, Azyumardi. Islam Nusantara: Jaringan Global dan Lokal, terj. Iding Rosyidin Hasan. Bandung: Mizan, 2002.

Baso, Ahmad. Islam Pasca-Kolonial: Perselingkuhan Reformisme Agama, Kolonialisme dan Liberalisme. Tangerang Selatan: Pustaka Afid, 2005.

Berg, L.C.W. Van Den. Hadramaut dan Koloni Arab di Nusantara, terj. Rahayu Hidayat. Jakarta: INIS, 1989.

Burhanuddin, Jajat. "Islam dan Kolonialisme: Sayyid Usman dan Islam di Indonesia Masa Penjajahan,” dalam Studia Islamika, Vol. 22, No. 1, 2015.

Burhanuddin, Jajat. Islam dalam Arus Sejarah Indonesia . Jakarta: Kencana, 2017.

Daulay, Haidar Putra. Pendidikan Islam dalam Perspektif Filsafat. Jakarta: Prenada, 2016.

Freitag Ulrike. Indian Ocean Migrants and StateFormation in Hadhramaut: Reforming the Homeland. Leiden: Brill NV, 2003.

Gobee, E. dan C. Adriaanse. Nasihat-Nasihat C. Snouck Hurgronje Semasa Kepegawaiannya Kepada Pemerintah Hindia Belanda 1889-1936, Seri Khusus INIS V. Jakarta: INIS, 1991.

Harahap, Syahrin. Metodologi Studi Tokoh dan Penulisan Biografi. Jakarta: Prenada, 2011.

Ilyas, Ahmad Fauzi. Warisan Intelektual Ulama Nusantara: Tokoh, Karya dan Pemikiran. Medan: Rawda Publishing, 2018.

Ja'far. "Tarekat dan Gerakan Sosial Keagamaan Shaykh Hasan Maksum," dalam Teosofi: Jurnal Tasawuf dan Pemikiran Islam, Vol. 5, No. 2 (December 7, 2015).

Kaptein, Nico J.G. Islam, Kolonialisme dan Zaman Modern di Hindia Belanda: Biografi Sayid Usman (1822-1914). Yogyakarta: Suara Muhammadiyah, 2017. 
Khuluq, Lathiful. "K.H. Hasyim Asy'ari’s Contribution to Indonesian Independence," dalam Studia Islamika, Vol. 5, No. 1, 1998.

Kiki, Rakhmad Zailani. Genealogi Intelektual Ulama Betawi: Melacak Jaringan Ulama Betawi dari awal Abad ke-19 sampai Abad ke-21. Jakarta: Pusat Pengkajian dan Pengembangan Islam Jakarta, 2011.

Mansur. 'Pemikiran Sayyid Usman Tentang Akhlak Manusia: Konsep Akhlak dan Implikasinya bagi Pengembangan Ilmu Pengetahuan.” Disertasi: UIN Sunan Kalijaga Yogyakarta, 2005.

Noer, Deliar. Gerakan Modern Islam di Indonesia. Jakarta: LP3ES, 1982.

Noupal, Muhammad. "Kontroversi Tentang Sayyid Usman bin Yahya (1822-1914) Sebagai Penasehat Snouck Hurgronje," dalam Conference Proceeding Annual International Conference on Islamic Studies (AICIS) XII, Surabaya, 5-8 November 2012.

Noupal, Muhammad. "Kritik Sayyid Usman bin Yahya terhadap Gerakan Pembaharuan Islam di Indonesia: Studi Sejarah Islam di Indonesia Abad 19 dan Awal Abad 20," dalam Jurnal Ilmu Agama, No. 2, Th. XIV, Desember, 2013.

Noupal, Muhammad. "Pemikiran Keagamaan Sayyid Usman bin Yahya (1822-1914): Respon dan Kritik Terhadap Kondisi Sosial Keagamaan di Indonesia.” Disertasi: UIN Syarif Hidayatullah Jakarta, 2008.

Nurhasanah. "Kontribusi Sayyid Usman dalam Kehidupan Keagamaan Masyarakat Islam Batavia (1862-1914).” Tesis: UIN Syarif Hidayatullah Jakarta, 2017.

Riau, Raja Ali al-Haji. Tuhfat al-Nafis: Sejarah Melayu dan Bugis. Singapura: Malaysia Printers, 1965.

Salminawati. "Etika Pendidik dalam Perspektif Imam al-nawawî," dalam MIQOT: Jurnal Ilmu-ilmu Keislaman, Vol. XL No. 2 Juli-Desember 2016. 
Steenbrink, Karel A. Beberapa Aspek Tentang Islam di Indonesia Abad ke-19. Jakarta: Bulan Bintang, 1984.

Wensinck, A. J. al-Mu ‘jam al-Mufahras li Alfâzh al-Hadîts alNabawi, Jilid I. Leiden: E. J. Brill, 1936.

Yahya, Sayyid Abdullah bin Usman bin Abdullah bin Aqil bin Umar bin. Sulûh Zamân. Jakarta: Percetakan Sayyid Utsman, t.t.

Yahya, Sayyid Alwi bin Usman bin Abdullah bin Aqil bin Umar bin. Qamar al-Zamân. Petamburan: Percetakan Sayyid Utsman, t.t.

Yahya, Sayyid Usman bin Abdullah bin Aqil bin Umar bin. Âdâb al-Insân. t.t.p.: Maktabah wa Mathba'ah Menara Kudus, t.t.

Yahya, Sayyid Usman bin Abdullah bin Aqil bin Umar bin. I'anât al-Mustarsyidîn 'alâ Ijtinâb al-Bida' fî al-Dîn. Batavia: Matba'ah al-Mubarakah, 1329/1911.

Yahya, Sayyid Usman bin Abdullah bin Aqil bin Umar bin. Risâlah Dua Ilmu. Jatinegara: al-Syirkah al-Thahiriyah li al-Nasyr, t.t. 


\section{Catatan Akhir:}

${ }^{1}$ Azyumardi Azra, Islam Nusantara: Jaringan Global dan Lokal, terj. Iding Rosyidin Hasan (Bandung: Mizan, 2002), h. 138.

${ }^{2}$ Nico J.G. Kaptein, Islam, Kolonialisme dan Zaman Modern di Hindia Belanda: Biografi Sayid Usman (1822-1914) (Yogyakarta: Suara Muhammadiyah, 2017), h.1-2.

${ }^{3}$ Ahmad Fauzi Ilyas, Warisan Intelektual Ulama Nusantara: Tokoh, Karya dan Pemikiran (Medan: Rawda Publishing, 2018), h. 75-77.

${ }^{4}$ Syahrin Harahap, Metodologi Studi Tokoh dan Penulisan Biografi (Jakarta: Prenada Media Group, 2011), h. 8.

${ }^{5}$ Muhammad Noupal, "Pemikiran Keagamaan Sayyid Usman bin Yahya (18221914): Respon dan Kritik Terhadap Kondisi Sosial Keagamaan di Indonesia" (Disertasi: UIN Syarif Hidayatullah Jakarta, 2008).

${ }^{6}$ Muhammad Noupal, "Kontroversi Tentang Sayyid Usman bin Yahya (1822-1914) Sebagai Penasehat Snouck Hurgronje," dalam Conference Proceeding Annual International Conference on Islamic Studies (AICIS) XII, Surabaya, 5-8 November 2012.

${ }^{7}$ Muhammad Noupal, "Kritik Sayyid Usman bin Yahya Terhadap Gerakan Pembaharuan Islam di Indonesia: Studi Sejarah Islam di Indonesia Abad 19 dan Awal Abad 20,” dalam Jurnal Ilmu Agama, No. 2, Th. XIV, Desember, 2013.

${ }^{8}$ Jajat Burhanuddin, "Islam dan Kolonialisme: Sayyid Usman dan Islam di Indonesia Masa Penjajahan," dalam Studia Islamika, Vol. 22, No. 1, 2015.

${ }^{9}$ Mansur, "Pemikiran Sayyid Usman Tentang Akhlak Manusia: Konsep Akhlak dan Implikasinya bagi Pengembangan Ilmu Pengetahuan” (Disertasi: UIN Sunan Kalijaga Yogyakarta, 2005).

${ }^{10}$ Nurhasanah, "Kontribusi Sayyid Usman dalam Kehidupan Keagamaan Masyarakat Islam Batavia (1862-1914)" (Tesis: UIN Syarif Hidayatullah Jakarta, 2017)

${ }^{11}$ Ahmad Athoillah, "Kritik Sayid Utsman bin Yahya terhadap Ideologi Jihad dalam Gerakan Sosial Islam pada Abad 19 dan 20," dalam Refleksi, Vol. 13, No. 5, Oktober 2013.

${ }^{12}$ Hasan Asari, Etika Akademis dalam Islam: Studi tentang Kitab Tazkirat alSami wa al-Mutakallim karya Ibn Jama’ah (Yogyakarta: Tiara Wacana, 2008).

${ }^{13}$ Hasan Asari, "the Educational Thought of al-Ghazali: Theory and Practice," (Thesis: McGill University, 1993).

${ }^{14}$ Salminawati, "Etika Pendidik dalam Perspektif Imam al-nawawî," dalam MIQOT: Jurnal Ilmu-ilmu Keislaman, Vol. XL No. 2 Juli-Desember 2016.

${ }^{15}$ Mahrus As'ad, 'Pembaruan Pendidikan Islam K.H. Hasyim Asy'ari," dalam Tsaqafah: Jurnal Peradaban Islam, Vol. 8, No. 1, 2012, pp. 105-134.

${ }^{16} \mathrm{Ja}$ 'far, "Tarekat dan Gerakan Sosial Keagamaan Shaykh Hasan Maksum," dalam Teosofi: Jurnal Tasawuf dan Pemikiran Islam, Vol. 5, No. 2 (December 7, 2015), pp. 269-293.

${ }^{17}$ Sayyid Abdullah bin Usman bin Abdullah bin Aqil bin Umar bin Yahya, 
Sulûh Zamân (Jakarta: Percetakan Sayyid Utsman, t.t.), h. 2.

${ }^{18}$ L.C.W. Van Den Berg menjelaskan bahwa sayyid adalah kelas khusus di antara penduduk Hadramaut yang dalam posisi sosialnya tidak berdagang, tidak berindustri dan tidak menyandang senjata. Pengaruh mereka sepenuhnya adalah moral. Mereka mendominasi dalam perihal agama dan hukum agama, sehingga dengan hal itu, mereka dihormati. Seorang sayyid akan dicium tangannya bahkan oleh mereka yang berusia lebih tua atau bahkan yang berpendidikan lebih tinggi. Lihat keterangan lengkap dalam L.C.W. Van Den Berg, Hadramaut dan Koloni Arab di Nusantara, terj. Rahayu Hidayat (Jakarta: INIS, 1989), h. 61-63.

${ }^{19}$ Kaptein, Islam, Kolonialisme dan Zaman Modern, h. 60-61.

${ }^{20}$ Noupal, "Kontroversi tentang Sayyid Usman bin Yahya," h. 1371.

${ }^{21}$ Sayyid Abdullah, Sulûh Zamân, h. 2.

${ }^{22}$ Sayyid Alwi bin Usman bin Abdullah bin Aqil bin Umar bin Yahya, Qamar al-Zamân (Petamburan: Percetakan Sayyid Utsman, t.t.), h. 2.

${ }^{23}$ Kaptein, Islam, Kolonialisme dan Zaman Modern, h. 64.

${ }^{24} \mathrm{Ibid}$, h.63.

${ }^{25}$ Sayyid Abdullah, Sulûh Zamân, h. 2-3.

${ }^{26}$ Rakhmad Zailani Kiki, Genealogi Intelektual Ulama Betawi: Melacak Jaringan Ulama Betawi dari awal Abad ke-19 sampai Abad ke-21 (Jakarta: Pusat Pengkajian dan Pengembangan Islam Jakarta (Jakarta Islamic Centre), 2011), h. 60-64.

${ }^{27}$ Raja Ali al-Haji Riau, Tuhfat al-Nafis: Sejarah Melayu dan Bugis (Singapura: Malaysia Printers, 1965).

${ }^{28}$ E. Gobee dan C. Adriaanse, Nasihat-Nasihat C. Snouck Hurgronje Semasa Kepegawaiannya Kepada Pemerintah Hindia Belanda 1889-1936(Jakarta: INIS, 1991), h. 900 .

${ }^{29}$ Sayyid Abdullah, Sulûh Zamân, h. 2-3.

${ }^{30}$ Kaptein, Islam, Kolonialisme dan Zaman Modern, h. 67.

${ }^{31}$ L.C.W. Van Den Berg, h.105.

${ }^{32}$ Sayyid Abdullah, Sulûh Zamân, h. 3.

${ }^{33}$ Sayyid Alwi, Qamar al-Zamân, h. 9.

${ }^{34}$ Jajat Burhanuddin berpendapat justru Abdurrahman al-Mishri, sang kakek yang meninggal dunia. Bukan ibundanya. Lihat Jajat Burhanuddin, Islam dalam Arus Sejarah Indonesia (Jakarta: Kencana, 2017), h. 300.

${ }^{35}$ Sayyid Abdullah, Sulûh Zamân, h. 3.

${ }^{36}$ Kaptein, Islam, Kolonialisme dan Zaman Modern, h. 69.

${ }^{37}$ Ibid, h. 26.

${ }^{38}$ Sayyid Alwi, Qamar al-Zamân h.3

${ }^{39}$ Sayyid Abdullah, Sulûh Zamân, h. 3.

${ }^{40}$ Ibid, h. 3. Lihat juga Sayyid Alwi, h.4

${ }^{41}$ Kaptein, Islam, Kolonialisme dan Zaman Modern, h. 71. 
${ }^{42}$ Sayyid Usman bin Abdullah bin Aqil bin Umar bin Yahya, I'anât al-Mustarsyidîn 'alâ Ijtinâb al-Bida' fi al-Dîn (Batavia: Matba’a al-Mubaraka, 1329/1911)

${ }^{43}$ Sayyid Abdullah, Sulûh Zamân, h. 3-4

${ }^{44}$ Kaptein, Islam, Kolonialisme dan Zaman Modern, h. 74-77.

${ }^{45}$ Ulrike Freitag, Indian Ocean Migrants and State Formation in Hadhramaut: Reforming the Homeland (Leiden: Brill NV, 2003), h. 61-77.

${ }^{46}$ Ibid, h. 227.

${ }^{47}$ Karel A. Steenbrink, Beberapa Aspek Tentang Islam di Indonesia Abad ke19 (Jakarta: Bulan Bintang, 1984), h.3 dan 14. Lihat juga Azyumardi Azra, Islam Nusantara: Jaringan Global dan Lokal, h. 164. Baca juga, Deliar Noer, Gerakan Modern Islam di Indonesia (Jakarta: LP3ES, 1982).

${ }^{48}$ Ibid, h. 82-84.

${ }^{49}$ Ilyas, Warisan Intelektual Ulama Nusantara, h. 75-77.

${ }^{50}$ Kalimat "dan lain sebagainya" mengindikasikan kemungkinan besar ada karyakarya lain yang belum tercatat.

${ }^{51}$ Kaptein, Islam, Kolonialisme dan Zaman Modern, h. 125.

${ }^{52}$ Ilyas, Warisan Intelektual Ulama Nusantara, h. 86.

${ }^{53}$ Sayyid Usman bin Abdullah bin Aqil bin Umar bin Yahya, Âdâb al-Insân (t.t.p.: Maktabah wa Mathba'ah Menara Kudus, t.t.), h. 4.

${ }^{54}$ Ibid, h. 5 .

${ }^{55}$ Ibid, h. 6 .

${ }^{56} \mathrm{Ibid}$, h. 8 .

${ }^{57}$ Ibid, h. 9.

${ }^{58} \mathrm{Ibid}$, h. 10.

${ }^{59} \mathrm{Ibid}$, h. 11.

${ }^{60}$ Ibid, h. 12.

${ }^{61} \mathrm{Ibid}$, h. 13.

${ }^{62}$ Ibid, h. 14.

${ }^{63}$ Ibid, h. 15.

${ }^{64}$ Ibid.

${ }^{65}$ Ibid, h. 16.

${ }^{66}$ Ibid.

${ }^{67} \mathrm{Ibid}$, h. 17.

${ }^{68}$ Ibid, h. 19.

${ }^{69}$ Ibid.

${ }^{70} \mathrm{Ibid}$, h. 21.

${ }^{71}$ Ibid, h. 22.

${ }^{72}$ Ibid, h. 24.

${ }^{73}$ Ibid, h. 25. 
${ }^{74}$ Ibid.

${ }^{75}$ Ibid, h. 26.

${ }^{76}$ Ibid, h. 27.

${ }^{77}$ Ibid.

${ }^{78}$ Ibid, h. 28.

${ }^{79}$ Ibid, h. 29.

${ }^{80}$ Tentang Hasyim Asy'ari, lihat Lathiful Khuluq, "K.H. Hasyim Asy'ari’s Contribution to Indonesian Independence," dalam Studia Islamika, Vol. 5, No. 1, 1998.

${ }^{81}$ Muhammad Hasyim Asy'arî al-Jambânî, Âdâb al-'Âlim wa al-Muta âllim: Fî Mâ Yahtaj Ilaih al-Muta'allim fi A fi Maqâmât Ta 'lîmih (Jombang: Pustaka Tebu Ireng, 2016), h. 88-91.

${ }^{82}$ Syed Muhammad Naquib al-Attas, the Concept of Education in Islam: A Framework for An Islamic Philosophy of Education (Kuala Lumpur: ISTAC, 1999), h. 1-36.

${ }^{83}$ Di antaranya adalah HR. al-Darimi dalam Fadhâ'il al-Qur'ân (100), atau HR. Ibn Majah dalam Âdâb (3). Lihat dalam A. J. Wensinck, al-Mu jam al-Mufahras $l i$ Alfâzh al-Hadîs al-Nabawi, Jilid I (Leiden: E. J. Brill, 1936), h. 36.

${ }^{84}$ Sayyid Usman, Âdâb al-Insân, h. 2.

${ }^{85}$ Ibid, h. 3.

${ }^{86}$ Tentang jabatan ini, Muhammad Noupal menyatakan bahwa pengangkatannya sebagai adviseur honorair tidak terdapat dalam karya-karya Sayyid Usman sendiri. Jabatan ini dipahami dari surat-surat yang dikirim Snouck Hurgronje kepada pemerintah pusat. Selengkapnya dapat dilihat dalam Muhammad Noupal, "Pemikiran Keagamaan Sayyid Usman bin Yahya," h. 19-80.

${ }^{87} \mathrm{Ahmad}$ Baso, Islam Pasca-Kolonial: Perselingkuhan Reformisme Agama, Kolonialisme dan Liberalisme (Tangerang Selatan: Pustaka Afid, 2005), h. 270-289.

${ }^{88}$ Noupal, "Kontroversi tentang Sayyid Usman bin Yahya," h. 1391.

${ }^{89}$ Haidar Putra Daulay, Pendidikan Islam dalam Perspektif Filsafat (Jakarta: Prenada, 2016), h. 89.

${ }^{90}$ Sayyid Usman, Âdâb al-Insân, h. 2.

${ }^{91}$ Ibid., h. 2.

${ }^{92}$ Ibid., h. 10-11.

${ }^{93}$ Ibid., Risâlah Dua Ilmu (Jatinegara: al-Syirkah al-Thahiriyah li al-Nasyr, t.t.), h. 3-4.

${ }^{94}$ Ibid., Âdâb al-Insân, h. 9. 